\title{
Nutrient Requirements for the Recovery of Tellurite Resistance by Heat-injured Streptococcus faecalis
}

\author{
By J. PAYNE \\ Agricultural Research Council Food Research Institute, Colney Lane, Norwich NR4 7UA
}

(Received 7 April 1978)

\begin{abstract}
Heat-injured Streptococcus faecalis recovered tellurite resistance in 4 to $5 \mathrm{~h}$ when incubated at $33{ }^{\circ} \mathrm{C}$ in a non-growth medium containing $\mathrm{KH}_{2} \mathrm{PO}_{4} / \mathrm{K}_{2} \mathrm{HPO}_{4}$ buffer $\mathrm{pH} 7 \cdot 1$, glucose and casein hydrolysate. Only $10 \%$ of the damaged population recovered in the absence of $\mathrm{K}^{+}$, or glucose, or casein hydrolysate, or in the presence of valinomycin in medium containing $1 \mathrm{mM}-\mathrm{K}^{+}$. The $\mathrm{K}^{+}$content of cells increased two- to threefold on heating and a further threeto sixfold during the first $30 \mathrm{~min}$ of subsequent incubation. The $\mathrm{Na}^{+}$content decreased simultaneously but $\mathrm{Mg}^{2+}$ concentrations were not affected. Recovery was not affected by adding $1 \mathrm{~mm}$-EDTA or $2 \mathrm{~mm}-\mathrm{Mg}^{2+}$ to the medium but the addition of $1 \mathrm{~mm}$-EDTA and $2 \mathrm{mM}-\mathrm{Mg}^{2+}$ together reduced recovery to $<20 \%$. This effect was reversed by adding $2 \mathrm{mM}-\mathrm{Ca}^{2+}$.
\end{abstract}

\section{INTRODUCTION}

Payne \& Morley (1976) reported that heat-injured Streptococcus faecalis recovered tellurite resistance in heart infusion broth before beginning to grow and divide. However, with media capable of supporting growth, it is not possible to distinguish between changes due to recovery of the damaged cells and those due to multiplication of cells that have already recovered.

Clark et al. (1968), investigating the recovery of salt tolerance by heat-injured Strep. faecalis $\mathrm{R} 57$, reported that recovery was lower in defined media than in trypticase soy broth. However, heat-injured cells of Staphylococcus aureus MF31 recovered salt tolerance when incubated in a medium containing glucose, phosphate buffer and a mixture of amino acids (Iandolo \& Ordal, 1966). Using the strain s6 of Staph. aureus, Hurst et al. (1973) found that heat-injured cells recovered in a diluted, dialysed medium that did not support growth of unheated cells, and more recent work has shown that this organism can recover from heatinjury in a medium containing only phosphate buffer, amino acids and $\mathrm{Mg}^{2+}$ (Hurst et al., 1975; Hughes \& Hurst, 1976).

This paper reports an investigation of the nutrient requirements for the recovery of tellurite resistance by heat-injured Strep. faecalis. The cation content of unheated and heated cells, before and after recovery, has also been determined.

\section{METHODS}

Heat-injury and recovery procedure. Streptococcus faecalis var. liquefaciens $\mathrm{EB} / \mathrm{F} / 30 / 39$ was grown and maintained as previously described (Payne \& Morley, 1976). Unless stated otherwise, cells were heated for $4 \mathrm{~min}$ at $60^{\circ} \mathrm{C}$ in heart infusion broth by diluting a suspension 50 - to 100 -fold into $50 \mathrm{ml}$ of pre-heated medium to give about $1 \times 10^{8}$ viable units $\mathrm{ml}^{-1}$ (Payne \& Morley, 1976). A portion (5 ml) of the heated suspension was harvested by membrane filtration (pore size $0.22 \mu \mathrm{m}$ ) and washed on the membrane with $2 \times 10 \mathrm{ml}$ of $100 \mathrm{mM} \mathrm{KH}_{2} \mathrm{PO}_{4} / \mathrm{K}_{2} \mathrm{HPO}_{4}$ or $\mathrm{NaH}_{2} \mathrm{PO}_{4} / \mathrm{Na}_{2} \mathrm{HPO}_{4}$ buffer $\mathrm{pH} 7 \cdot 1$ before being resuspended in $50 \mathrm{ml}$ of recovery medium and incubated at $33^{\circ} \mathrm{C}$ on a rotary shaker. The standard recovery medium, that 


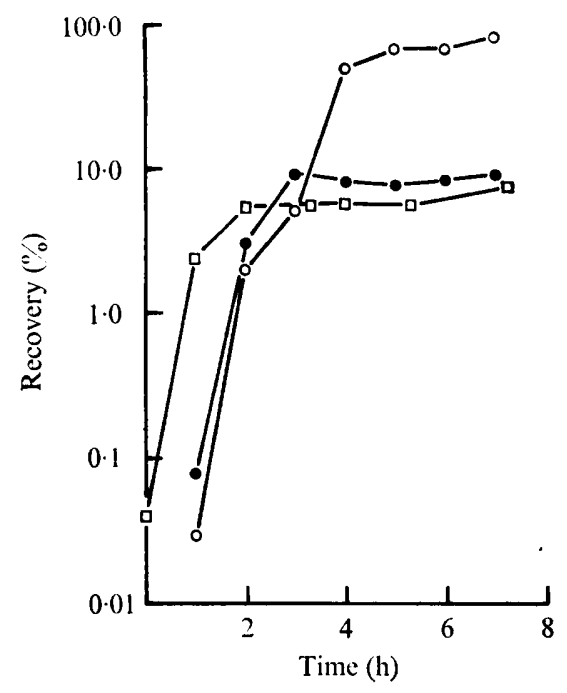

Fig. 1

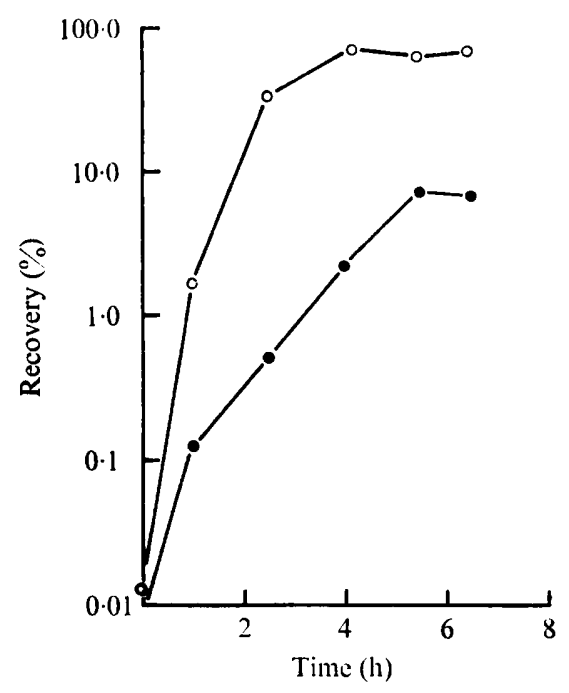

Fig. 2

Fig. 1. Recovery of tellurite resistance by heat-injured Strep. faecalis in standard recovery medium. Cells were heated in heart infusion broth for $4 \mathrm{~min}$ at $60^{\circ} \mathrm{C}$, harvested by membrane filtration, washed in $100 \mathrm{~mm}-\mathrm{KH}_{2} \mathrm{PO}_{4} / \mathrm{K}_{2} \mathrm{HPO}_{4}$ buffer pH $7 \cdot 1$ and resuspended at about $1 \times 10^{7}$ viable units $\mathrm{ml}^{-1}$ in $(a)$ complete recovery medium $(O),(b)$ recovery medium minus glucose $(O)$ or $(c)$ recovery medium minus casein hydrolysate $(\square)$. Cell suspensions were incubated at $33^{\circ} \mathrm{C}$ with shaking and samples were removed at intervals for serial dilution and viable count on heart infusion agar with or without $0.04 \%$ potassium tellurite. Recovery is the count in the presence of tellurite expressed as a percentage of the count in the absence of tellurite.

Fig. 2. Requirement for $\mathrm{K}^{+}$during recovery of tellurite resistance by heat-injured Strep. faecalis. Cells were heated as in Fig. 1 and allowed to recover at $33{ }^{\circ} \mathrm{C}$ in $100 \mathrm{mM}-\mathrm{NaH}_{2} \mathrm{PO}_{4} / \mathrm{Na}_{2} \mathrm{HPO}_{4}$ buffer pH $7 \cdot 1$ containing $0.5 \%$ glucose and $0.1 \%$ casein hydrolysate with $(O)$ or without $(\bullet) 1 \mathrm{mM}-\mathrm{KCl}$. Recovery is expressed as in Fig. 1.

did not support growth, contained $100 \mathrm{mM}-\mathrm{KH}_{2} \mathrm{PO}_{4} / \mathrm{K}_{2} \mathrm{HPO}_{4}$ buffer $\mathrm{pH} 7 \cdot 1,0 \cdot 5 \%$ (w/v) glucose and $0.1 \%(\mathrm{w} / \mathrm{v})$ casein hydrolysate (Oxoid). The three components were autoclaved $\left(121^{\circ} \mathrm{C}\right.$ for $\left.15 \mathrm{~min}\right)$ separately and combined before use. Where required $\mathrm{KCl}, \mathrm{MgSO}_{4} \cdot 7 \mathrm{H}_{2} \mathrm{O}$ and EDTA were added as filtersterilized solutions. Valinomycin (Sigma) was dissolved in ethanol and added to the recovery medium so that the final concentration of valinomycin was $5 \mu \mathrm{g} \mathrm{ml}^{-1}$ and that of ethanol was $<1 \%(\mathrm{v} / \mathrm{v})$.

Viable counts. These were carried out as previously described (Payne \& Morley, 1976).

Preparation of samples for cation determination. In experiments where cation concentrations were to be determined, cells were heated in $50 \mathrm{ml}$ of heart infusion broth at about $1 \times 10^{9}$ viable units $\mathrm{ml}^{-1}$, then harvested by centrifuging $\left(12000 \mathrm{~g}, 5 \mathrm{~min}, 10^{\circ} \mathrm{C}\right)$, washed in sterile glass-distilled water, centrifuged $\left(25000 \mathrm{~g}, 12 \mathrm{~min}, 10^{\circ} \mathrm{C}\right.$ ) and resuspended in 1 litre of recovery medium. Such treatments resulted in cell suspensions with a viable count on heart infusion agar of about $5 \times 10^{7}$ viable units $\mathrm{ml}^{-1}$ and a total microscopic count of about $6 \times 10^{7}$ diplococci $\mathrm{ml}^{-1}$ plus $2 \times 10^{6}$ chains of three or more cells. After incubation, cells were harvested by membrane filtration (pore size $0.22 \mu \mathrm{m}$ ) and resuspended in glass-distilled water. Unheated, heated and recovered cells were washed twice in glass-distilled water and finally resuspended in $10 \mathrm{ml}$ of glass-distilled water and stored in plastic bottles at $4{ }^{\circ} \mathrm{C}$. Duplicate dry wt determinations were carried out on $1 \mathrm{ml}$ samples of these washed cell suspensions. Duplicate $3 \mathrm{ml}$ samples were wet-ashed with $1 \mathrm{ml}$ concentrated nitric acid, made up to $10 \mathrm{ml}$ with glass-distilled water and stored in plastic bottles at $4{ }^{\circ} \mathrm{C}$ prior to atomic absorption spectroscopy. Samples of recovery medium were similarly treated.

Atomic absorption spectroscopy. $\mathrm{Mg}^{2+}, \mathrm{K}^{+}$and $\mathrm{Na}^{+}$in ashed samples were determined by atomic absorption spectroscopy using a Varian AA6 spectrophotometer at $285 \cdot 2,769.9$ and $589.6 \mathrm{~nm}$, respectively. Concentrations were determined from calibration curves obtained with standard solutions and results were corrected for blank digests of glass-distilled water. 


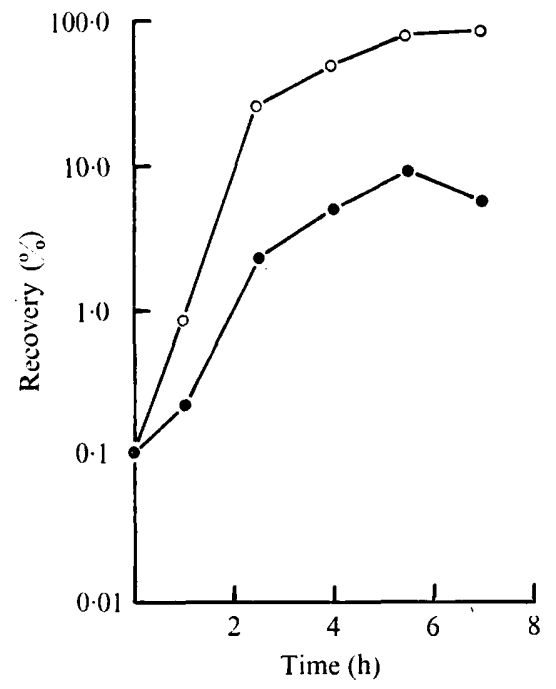

Fig. 3

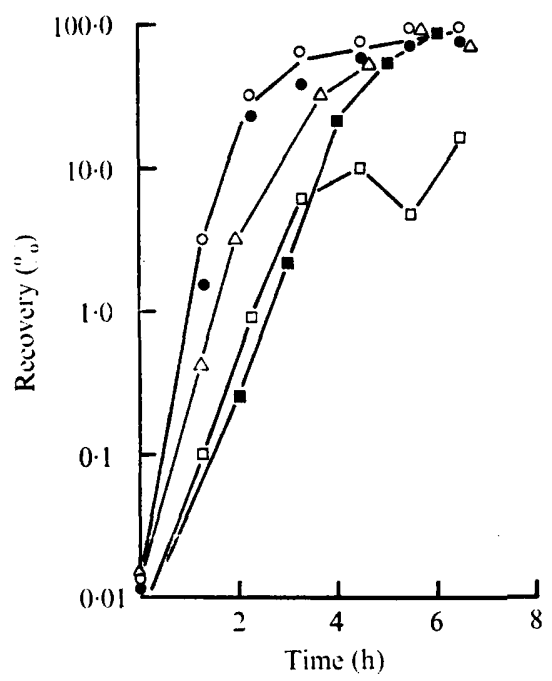

Fig. 4

Fig. 3. Effect of valinomycin and $\mathrm{K}^{+}$concentration on recovery of tellurite resistance by heatinjured Strep. faecalis. Cells were heated as in Fig. 1 and allowed to recover at $33{ }^{\circ} \mathrm{C}$ in $\mathrm{NaH}_{2} \mathrm{PO}_{4} /$ $\mathrm{Na}_{2} \mathrm{HPO}_{4}$ buffer $\mathrm{pH} 7 \cdot 1$ containing $0.5 \%$ glucose, $0.1 \%$ casein hydrolysate and $5 \mu \mathrm{g}$ valinomycin $\mathrm{ml}^{-1}$ plus either $1 \mathrm{~mm}-\mathrm{KCl}(0)$ or $100 \mathrm{~mm}-\mathrm{KCl}(\mathrm{O})$. Recovery is expressed as in Fig. 1.

Fig. 4. Effect of EDTA and $\mathrm{Mg}^{2+}$ on recovery of tellurite resistance by heat-injured Strep. faecalis. Cells were heated as in Fig. 1 and allowed to recover at $33{ }^{\circ} \mathrm{C}$ in $(a) 100 \mathrm{~mm}-\mathrm{KH}_{2} \mathrm{PO}_{4} / \mathrm{K}_{2} \mathrm{HPO}_{4}$ buffer pH $7 \cdot 1$ containing $0.5 \%$ glucose and $0.1 \%$ casein hydrolysate $(O),(b)$ medium $(a)$ plus 1 mM-EDTA (O), (c) medium $(a)$ plus 2 mM-MgSO$_{4}(\boldsymbol{a}),(d)$ medium $(a)$ plus 1 mM-EDTA and

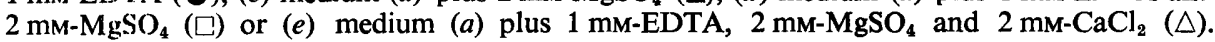
Recovery is expressed as in Fig. 1.

\section{RESULTS}

\section{Effect of medium constituents on recovery of heated cells}

When undamaged or heat-injured cells of Strep. faecalis were suspended in the standard recovery medium the colony count on heart infusion agar remained constant for at least $30 \mathrm{~h}$. The colony count of heat-injured cells on heart infusion agar containing $0.04 \%(\mathrm{w} / \mathrm{v})$ potassium tellurite was about $0.01 \%$ of the count on agar without tellurite on immediate plating but showed an increase within 4 to $5 \mathrm{~h}$ which represented recovery of tellurite resistance (Fig. 1). When either glucose or casein hydrolysate was omitted from the recovery medium, less than $10 \%$ of the injured population recovered (Fig. 1). When the potassium phosphate buffer was replaced by sodium phosphate buffer, less than $10 \%$ of the injured population recovered, but addition of $1 \mathrm{mM}-\mathrm{K}^{+}$to this medium restored recovery to the normal level (Fig. 2).

\section{Effect of valinomycin on recovery of heated cells}

Addition of $5 \mu \mathrm{g}$ valinomycin $\mathrm{ml}^{-1}$ and $1 \mathrm{~mm}-\mathrm{K}^{+}$to sodium phosphate recovery medium resulted in recovery of less than $10 \%$ of the heat-injured cells (Fig. 3). However, normal recovery was restored when the $\mathrm{K}^{+}$concentration was increased 100 -fold.

\section{Cation content of unheated, heated and recovered cells}

During heat-treatment, the $\mathrm{K}^{+}$content of the cells increased two- to three-fold while the $\mathrm{Na}^{+}$content decreased slightly (Table 1). After $30 \mathrm{~min}$ incubation of heat-injured cells in recovery medium, comparison of colony counts on heart infusion agar with and without tellurite indicated that there was very little recovery but the $\mathrm{Na}^{+}$content of the cells had decreased further and the $\mathrm{K}^{+}$content had increased a further three- to sixfold. Incubation 
Table 1. $\mathrm{K}^{+}, \mathrm{Na}^{+}$and $\mathrm{Mg}^{2+}$ contents of unheated, heated and recovered cells of Strep. faecalis

Unheated cells, or cells heated for $4 \mathrm{~min}$ at $60^{\circ} \mathrm{C}$ in heart infusion broth, or cells heat-injured and allowed to recover at $33{ }^{\circ} \mathrm{C}$ in $100 \mathrm{mM}-\mathrm{KH}_{2} \mathrm{PO}_{4} / \mathrm{K}_{2} \mathrm{HPO}_{4}$ buffer $\mathrm{pH} 7 \cdot 1$ containing $0.5 \%$ glucose and $0.1 \%$ casein hydrolysate, or unheated cells incubated in similar medium, were washed twice in glass-distilled water. The $\mathrm{K}^{+}, \mathrm{Na}^{+}$and $\mathrm{Mg}^{2+}$ contents were determined by atomic absorption spectroscopy of duplicate samples of cells wet-ashed with nitric acid.

\begin{tabular}{|c|c|c|c|c|c|}
\hline & \multirow{2}{*}{$\begin{array}{l}\text { Time in } \\
\text { recovery } \\
\text { medium } \\
\text { (h) }\end{array}$} & \multirow[b]{2}{*}{ Expt } & \multicolumn{3}{|c|}{ Cation content $\left[\mu \mathrm{g}(\mathrm{mg} \text { dry wt })^{-1}\right]$} \\
\hline & & & $\mathbf{K}^{+}$ & $\mathrm{Na}^{+}$ & $\mathbf{M g}^{2+}$ \\
\hline \multirow[t]{3}{*}{ Unheated cells } & 0 & $\begin{array}{l}\text { A } \\
\text { B } \\
\text { C } \\
\text { D } \\
\text { E }\end{array}$ & $\begin{array}{l}2.21 \\
3.79 \\
2.04 \\
3.33 \\
1.73\end{array}$ & $\begin{array}{r}9.80 \\
11.53 \\
9.97 \\
11 \cdot 13 \\
9.56\end{array}$ & $\begin{array}{l}2.65 \\
2 \cdot 62 \\
2 \cdot 50 \\
2 \cdot 53 \\
2.64\end{array}$ \\
\hline & 0.5 & A & $26 \cdot 55$ & $4 \cdot 60$ & 1.96 \\
\hline & $6 \cdot 0$ & $\mathbf{A}$ & $33 \cdot 16$ & $2 \cdot 94$ & $2 \cdot 16$ \\
\hline Heated cells & 0 & $\begin{array}{l}\text { B } \\
\mathbf{C} \\
\mathbf{E}\end{array}$ & $\begin{array}{l}9.26 \\
7.63 \\
3.46\end{array}$ & $\begin{array}{r}10.46 \\
6.88 \\
9 \cdot 30\end{array}$ & $\begin{array}{l}3 \cdot 60 \\
3 \cdot 25 \\
2 \cdot 83\end{array}$ \\
\hline \multirow[t]{2}{*}{-} & 0.5 & $\begin{array}{l}\mathbf{B} \\
\mathbf{E}\end{array}$ & $\begin{array}{l}31 \cdot 52 \\
21 \cdot 28\end{array}$ & $\begin{array}{l}5 \cdot 80 \\
4 \cdot 81\end{array}$ & $\begin{array}{l}2.98 \\
2 \cdot 34\end{array}$ \\
\hline & $6 \cdot 0$ & $\begin{array}{l}\text { C } \\
\text { D }\end{array}$ & $\begin{array}{l}20 \cdot 35 \\
28 \cdot 30\end{array}$ & $\begin{array}{l}5 \cdot 22 \\
2 \cdot 29\end{array}$ & $\begin{array}{l}2 \cdot 32 \\
2.99\end{array}$ \\
\hline
\end{tabular}

for up to $6 \mathrm{~h}$ resulted in no significant further change in the $\mathrm{K}^{+}$and $\mathrm{Na}^{+}$contents of the cells (Table 1). Unheated cells incubated under the same conditions showed similar changes in $\mathrm{K}^{+}$and $\mathrm{Na}^{+}$contents. The level of $\mathrm{Mg}^{2+}$ in the samples showed little change.

\section{Effect of EDTA and $\mathrm{Mg}^{2+}$ on recovery}

Heat-injured cells of Strep. faecalis may not require an exogenous source of $\mathrm{Mg}^{2+}$ in order to recover tellurite resistance since no marked changes in $\mathrm{Mg}^{2+}$ content were detected during either heat treatment or recovery. $\left(\mathrm{Mg}^{2+}\right.$ was present in the recovery medium as an impurity at $3.3 \mu \mathrm{M}$.) Addition of $1 \mathrm{mM}$-EDTA or $2 \mathrm{mM}$ extra $\mathrm{Mg}^{2+}$ had little effect on recovery although the $\mathrm{Mg}^{2+}$ did reduce the initial rate of recovery without affecting the final level (Fig. 4). However, addition of $1 \mathrm{~mm}-\mathrm{EDTA}$ and $2 \mathrm{~mm}-\mathrm{Mg}^{2+}$ together allowed less than $20 \%$ of the injured population to recover. This effect could be reversed by adding $2 \mathrm{mM}-\mathrm{Ca}^{2+}$ (Fig. 4).

\section{DISCUSSION}

The results presented in this paper show that heat-injured cells of Strep.faecalis recovered tellurite resistance in a medium that did not support growth. Most previous studies on the recovery from heat-injury of non-sporing bacteria have been with cells incubated in media permitting growth or in the presence of penicillin to inhibit growth (for review, see Tomlins \& Ordal, 1976).

In this study, a requirement for $\mathrm{K}^{+}$, glucose and a source of amino acids during recovery has been demonstrated. Payne \& Morley (1976) reported that heat-injured cells failed to recover normally in the presence of chloramphenicol, suggesting that ability to synthesize protein was a prerequisite for recovery. The dependence of recovery on a supply of amino acids is consistent with this and such a requirement may partly explain the involvement of $\mathrm{K}^{+}$. In Escherichia coli, the process most sensitive to $\mathrm{K}^{+}$deprivation is protein synthesis 
(Lubin \& Ennis, 1964), while in Strep. faecalis, $\mathrm{K}^{+}$-depleted cells are incapable of incorporating $\left[{ }^{14} \mathrm{C}\right]$ leucine into protein (Harold \& Baarda, 1968). Glucose most likely provided the energy for the injured cells to accumulate $\mathrm{K}^{+}$and amino acids: the generation of a protonmotive force is required for the active transport of certain metabolites (for reviews, see Hamilton, 1975; Simoni \& Postma, 1975) and the relationship between glycolysis, the membrane-bound ATPase and the generation of this potential in Strep. faecalis has been adequately demonstrated (Harold \& Baarda, 1969; Harold et al., 1970a, b; Harold \& Papineau, 1972).

Valinomycin inhibits the growth of Strep. faecalis by interfering with the selective accumulation of $\mathrm{K}^{+}$(Harold \& Baarda, 1967), this inhibition being overcome by adding excess $\mathrm{K}^{+}$. In the present study, valinomycin inhibited recovery but, again, addition of excess $\mathrm{K}^{+}$ reversed the effect, indicating that during recovery the damaged cells need to accumulate $\mathrm{K}^{+}$. Glycolysing cells have been shown to accumulate $\mathrm{K}^{+}$(Zarlengo \& Schultz, 1966; Harold \& Baarda, 1967, 1968), and the present results agree with these earlier reports and show that, during recovery, heated cells require and accumulate $\mathrm{K}^{+}$, suggesting that at least some of the metabolic processes characteristic of undamaged, non-growing cells are essential for recovery of heat-injured cells. These results differ from those obtained with heated Staph. aureus $\mathrm{s} 6$ (Hurst et al., 1973) in which $\mathrm{K}^{+}$and $\mathrm{Na}^{+}$are not required for recovery from thermal injury (Hughes \& Hurst, 1976).

Although no $\mathrm{Mg}^{2+}$ was added to the recovery medium, the amount present as an impurity may have satisfied a similar $\mathrm{Mg}^{2+}$ requirement to that observed with Staph. aureus s6 (Hurst et al., 1975; Hughes \& Hurst, 1976). However, with Staph. aureus, a $\mathrm{Mg}^{2+}$ requirement could be demonstrated by adding 1 mM-EDTA, but no such requirement was observed with heat-injured Strep. faecalis. Even in the presence of 10 mM-EDTA with no added $\mathrm{Mg}^{2+}$, recovery was only slightly affected (results not shown). The observation that added $\mathbf{M g}^{2+}$ failed to stimulate recovery supports this conclusion and seems reasonable since the cells did not lose $\mathrm{Mg}^{2+}$ during heating. The effect on recovery of EDTA plus $\mathrm{Mg}^{2+}$ and its reversal by $\mathrm{Ca}^{2+}$ suggest an effect of EDTA-Mg chelate on heated cells since, in the presence of $\mathrm{Ca}^{2+}$ and $\mathrm{Mg}^{2+}$, EDTA binds $\mathrm{Ca}^{2+}$ preferentially (see Martell \& Calvin, 1953).

I wish to thank Drs J. L. Peel and W. M. Waites for critical reading of the manuscript, Mr A. M. C. Davies for the atomic absorption spectroscopy and Miss J. E. Armes for technical assistance.

\section{REFERENCES}

Clark, C. W., Witter, L. D. \& Ordal, Z. J. (1968). Thermal injury and recovery of Streptococcus faecalis. Applied Microbiology 16, 1764-1769.

Hamiton, W. A. (1975). Energy coupling in microbial transport. Advances in Microbial Physiology 12, 1-53.

HAROLD, F. M. \& BAARDA, J. R. (1967). Gramicidin, valinomycin and cation permeability of Streptococcus faecalis. Journal of Bacteriology 94, 53-60.

HAROLD, F. M. \& BAARDA, J. R. (1968). Effects of nigericin and monactin on cation permeability of Streptococcus faecalis and metabolic capacities of potassium depleted cells. Journal of Bacteriology 95, 816-823.

HAROLD, F. M. \& BAARDA, J. R. (1969). Inhibition of membrane-bound adenosine triphosphatase and of cation transport in Streptococcus faecalis by $N, N^{\prime}$-dicyclohexylcarbodiimide. Journal of Biological Chemistry 244, 2261-2268.

Harold, F. M. \& Papineau, D. (1972). Cation transport and electrogenesis by Streptococcus faecalis. II. Proton and sodium extrusion. Journal of Membrane Biology 8, 45-62.

Harold, F. M., BaARda, J. R. \& Pavlasova, E. $(1970 a)$. Extrusion of sodium and hydrogen ions as the primary process in potassium ion accumulation by Streptococcus faecalis. Journal of Bacteriology 101, 152-159.

Harold, F. M., Pavlasova, E. \& BaArda, J. R. $(1970 \mathrm{~b})$. A transmembrane $\mathrm{pH}$ gradient in Streptococcus faecalis. Origin and dissipation by proton conductors and $N, N^{\prime}$-dicyclohexylcarbodiimide. Biochimica et biophysica acta 196, 235-244.

Hughes, A. \& HuRST, A. (1976). Magnesium requirement of Staphylococcus for repair from sub-lethal heat injury. Canadian Journal of Microbiology 22, 1202-1205.

Hurst, A., Hưghes, A., Beare-Rogers, J. L. \& Collins-Thompson, D. L. (1973). Physiological studies on the recovery of salt tolerance by Staphylococcus aureus after sub-lethal heating. Journal of Bacteriology 116, 901-907. 
Hurst, A., Hughes, A., Duckworth, M. \& BADDILEY, J. (1975). Loss of $\mathrm{D}$-alanine during sub-lethal heating of Staphylococcus aureus $\mathbf{5 6}$ and magnesium binding during repair. Journal of General Microbiology 89, 277-284.

IANDOLO, J. J. \& ORDAL, Z. J. (1966). Repair of thermal injury of Staphylococcus aureus. Journal of Bacteriology 91, 134-142.

LUBIN, M. \& ENNIS, H. L. (1964). On the role of intracellular potassium in protein synthesis. Biochimica et biophysica acta 80, 614-631.

MaRTell, A. E. \& Calvin, M. (1953). Chemistry of the Metal Chelate Compounds, p. 488. New York: Prentice-Hall.

Payne, J. \& Morley, J. S. (1976). Recovery of tellurite resistance by heat-injured Streptococcus faecalis. Journal of General Microbiology 94, 421-424.

Simon, R. D. \& Postma, P. W. (1975). The energetics of bacterial active transport. Annual Review of Biochemistry 44, 523-554.

TOMLINS, R. I. \& ORDAL, Z. J. (1976). Thermal injury and inactivation in vegetative bacteria. In Inhibition and Inactivation of Vegetative Microbes, pp. 153-190. Edited by F. A. Skinner \& W. B. Hugo. London and New York: Academic Press. ZARLengo, M. H. \& Schultz, S. G. (1966). Cation transport and metabolism in Streptococcus faecalis. Biochimica et biophysica acta 126, 308320. 